\title{
Implementasi Akhlak Terhadap Pergaulan Islami pada Remaja
}

\author{
Anisa Maulidani' ${ }^{1}$ Fuady Anwar ${ }^{2}$, Wirdati $^{3}$ \\ anisamaulidani3@gmail.com¹ ${ }^{1}$, uadyanwar@fis.unp.ac.id², wirdati@fis.unp.ac.id ${ }^{3}$ \\ Universitas Negeri Padang $1,2,3$
}

\begin{tabular}{|c|c|}
\hline ARTICLE INFO & ABSTRAK \\
\hline Article history: & \multirow{11}{*}{$\begin{array}{l}\text { This study aims to explore how the implementation of } \\
\text { Islamic social morality in adolescents in Korong Balah Aie. } \\
\text { The type of research used is field research or field research, } \\
\text { namely research in which data and information are } \\
\text { obtained directly in the field. Data were collected through } \\
\text { direct interviews with three informants consisting of } \\
\text { teenagers, parents, and village officials. To support the } \\
\text { interview data, the writer also took observation and } \\
\text { documentation data. Interview data were analyzed through } \\
\text { the stages of taking, reducing, and presenting data and } \\
\text { ending with drawing conclusions. Overall, the results of the } \\
\text { study indicate that adolescents do not fully understand and } \\
\text { implement Islamic social morals. Related to that, the data } \\
\text { actually found that there were eight important indicators } \\
\text { related to how the actual application of the concept of } \\
\text { Islamic association for moral development for teenagers. } \\
\text { The eight indicators are: covering the genitals, staying } \\
\text { away from adultery, prohibiting a young couple to be alone, } \\
\text { praying, saying good manners, being devoted to parents, } \\
\text { smoking bans for teenagers, saying greetings when meeting } \\
\text { fellow Muslims. We can use these eight indicators as a } \\
\text { reference by teenagers in carrying out Islamic social } \\
\text { morality because based on the results of research it has } \\
\text { been proven to be able to apply Islamic social morals. }\end{array}$} \\
\hline Received, 05 Agustus 2021 & \\
\hline Revised, 24 Agustus 2021 & \\
\hline $\begin{array}{l}\text { Accept } \\
2021\end{array}$ & \\
\hline Keywords: & \\
\hline & \\
\hline & \\
\hline Conflict of Interest: & \\
\hline None & \\
\hline Funding: & \\
\hline None & \\
\hline
\end{tabular}

Corresponding Author: Anisa Maulidani, Department Islamic Education Faculty of Social Science Universitas Negeri Padang, Indonesia, Email: anisamaulidani3@gmail.com Phone No: $+6282391161804$

\begin{tabular}{llll}
\hline & Cc $(7)$ & Copyright(C2022, Author(s) \\
\hline
\end{tabular}

\section{Pendahuluan}

Akhlak pergaulan remaja telah diatur oleh agama secara Islami, Alquran dan sunnah juga sudah menjelaskan perihal tatacara bergaul yang memiliki batasan dan dilandasi oleh agama. Oleh sebab itu perilaku tersebut harus diperhatikan, dipelihara dan dilaksanakan oleh para remaja, khususnyan remaja di Korong Balah Aie, Kenagarian Koto Tinggi kecamatan Enam Lingkung kabupaten Padang Pariaman. Sebagaimana yang telah diketahui bahwa agama Islam sudah mengajarkan anak didik agar menjadi seorang remaja muslim yang beretika, berakhlaqul karimah dan dapat menjadi seorang pemimpin yang fleksibel (tidak kaku/bisa menyesuaikan) 
bagi masyarakat di masa yang akan datang karena setiap orang pasti akan menjadi seorang pemimpin.

Menurut (Anirah dan Hasnah, 2013), saat ini kesan yang ada dalam benak masyarakat tentang perilaku remaja justru cenderung kebanyakan negatif. Dimulai dari perkelahian antar pelajar, pornografi, pacaran, kebut-kebutan, tindakan kriminal seperti pencurian, dan perampasan barang orang lain, pengedaran obatobat terlarang dan bahkan yang lebih heboh adalah dampak pergaulan bebas yang semakin mengkhawatirkan. Remaja akan mudah terjerumus keberbagai penyelewengan dan kerusakan akhlak dengan melakukan perampasan hak orang lain, pelecehan seksual, pembunuhan, dan timbulah persaingan tidak sehat demi untuk mendapatkan apa yang diinginkan dan didapati.

Menurut penulis, banyak remaja yang masih belum berprilaku sesuai dengan ajaran Islam seperti tidak mengucapkan salam saat bertemu teman atau orang tua di jalan, ugal-ugalan dijalan, pacaran, perkelahian antar remaja. Berdasarkan pengamatan penulis, dilokasi penelitian melihat bahwa dari 30 remaja di Korong Balah Aie hanya 15 orang remaja yang berakhlak baik. Namun, penulis belum melihat remaja yang mengucapkan salam saat bertemu, dan hanya 3 orang remaja yang mengaku tidak pacaran. Maka menurut penulis perlu menjelaskan implementasi akhlak terhadap pergaulan Islami remaja di Korong Balah Aie Kenagarian Koto Tinggi Padang Pariaman agar remaja berakhlak baik.

Pergaulan remaja diidentikkan dengan pergaulan bebas dan tidak sedikit dari remaja yang salah dalam memilih pergaulan. Akibat dari salah memilih pergaulan diantaranya perlakuan yang semakin brutal, menggunakan barang barang terlarang, semakin jauh dari orang tua, sering membolos saat sekolah berpacaran, tidak mengucapkan salam saat bertemu, belum melaksanakan sholat lima waktu dan sebagainya.

Menurut Al-Tahanawi akhlak berarti perilaku, sifat, hal-ihwal, attitude, perangai, budi pekerti dan karakter yang sudah tertanam dalam jiwa manusia. Sedangkan ilmu akhlak ialah ilmu tentang perilaku ('ulum al-suluk) sebagai pengetahuan tentang apa yang baik dan yang buruk (Nasaruddin,2015: 203).

Akhlak yang baik, disebut akhlak terpuji dan akhlak yang buruk disebut akhlak tercela. Akhlak yang bermakna perilaku, merupakan perilaku kejiwaan yang tertanam dalam diri manusia, ia merupakan potensi cenderung kepada yang baik dan buruk (Nasaruddin,2015: 203).

Masyarakat menyadari kondisi sekarang tentang meningkatnya kenakalan remaja akhir-akhir ini. Masalah kenakalan remaja ini mengkhawatirkan berbagai pihak, antara lain orang tua, masyarakat, ulama bahkan pemerintah yang berkepentingan terhadap keberhasilan penbangunan Nasional. Kenakalan remaja adalah perilaku menyimpang dan dapat menimbulkan kerugian-kerugian baik pada diri anak remaja, keluarga dan masyarakat (Suyono dkk, 2014).

Berdasarkan uraian diatas penulis tertarik untuk mengetahui lebih lanjut mengenai implementasi akhlak terhadap pergaulan Islami remaja di Korong Balah Aie. Penelitian serupa juaga pernah diteliti oleh Mei Dian Tarini, dengan judul "Pembinaan Akhlak Bagi Remaja Di Panti Asuhan Darul Hadlonah Purbalingga". Penulisan ini membahas tentang pembinaan akhlak yang dilakukan oleh pengurus YKM Muslimat NU kabupaten Purbalingga terhadap anak yatim piatu dan duafa 
Anisa Maulidani, Fuady Anwar, dan Wirdati: Implementasi Akhlak dalam Pergaulan Islami ...

remaja di Panti Asuhan Darul Hadlonah Purbalingga. Perbedaan penulisan pada skripsi yang ditulis oleh Mei Dian Tarini, terdapat pada latar belakang masalah mengenai, Panti asuhan Darul Hadlonah Purbalingga sebagai salah satu yayasan yang bergerak di bidang sosial khususnya menanggulangi anak yatim, piatu, yatim piatu dan du'afa. Dalam hal ini, mereka merupakan anak-anak dari kalangan keluarga tidak mampu serta tidak mempunyai ayah, ibu atau keduanya. Sedangkan sedangkan penelitian yang penulis teliti mengenai konsep pergaulan Islami untuk pembinaan akhlak bagi remaja untuk menerapkan konsep pergaulan Islami untuk pembinaan akhlak bagi remaja itu sendiri.

Selanjutnya penelitian yang dilakukan oleh Sakina Wulandari, yang berjudul "Pembinaan Akhlak Peserta Didik Di SMA N 1 Sumber Jaya Lampung Barat". pembinaan yang dilakukan agar peserta didik berprilaku baik dan tindakannya tidak melenceng dari norma yang ada di SMA Negeri 1 Sumber Jaya. Tujuan dari penulisan ini adalah untuk mengetahui penerapan metode pembiasaan yang digunakan dalam menumbuhkan moral peserta didik di SMA N 1 Sumber Jaya, Lampung Barat. Perbedaan dengan penelitian yang penulis lakukan yaitu terdapat pada objek penelitian, jika penelitian yang dilakukan oleh Sakina Wulandari pada peserta didik SMA N 1 Sumber Jaya, Lampung Barat, sedangkan penelitian yang penulis lakukan pada remaja di Korong Balah Aie.

Tujuan penelitian ini adalah untuk mengetahui implementasi akhlak terhadap pergaulan Islami remaja di Korong Balah Aie. Manfaat penelitian ini yaitu sebagai berikut: 1) Secara teoritis: penelitian ini diharapkan dapat memaparkan dan menjelaskan kepada masyarakat khususnya remaja tentang implementasi akhlak terhadap pergaulan Islami remaja. 2) Secara praktis: Hasil penulisan ini dapat menambah wawasan serta masukan untuk masyarakat terkait dengan implementasi akhlak terhadap pergaulan Islami remaja. 3) Penulis: Penelitian ini diajukan sebagai salah satu syarat untuk memperoleh gelar sarjana S1 Jurusan Ilmu Agama Islam Fakultas Ilmu Sosial Universitas Negeri Padang.

\section{Tinjauan Pustaka}

Akhlak dapat diartikan menjadi dua yaitu akhlak menurut bahasa (etimologi) dan yang kedua menurut istilah (terminologi). Menurut Muhammad Said, pengertian Akhlak secara etimologi berasal dari "خلق" (Khuluqun) yang berarti budi pekerti, perangai, tingkah laku dan tabiat (Muhammad Abdurrahman, 2019:6).

Menurut Ali Abdul Halim Mahmud, Akhlak secara terminologi ialah sebuah sistem yang lengkap yang terdiri dari karakteristik-karakteristik akal atau tingkah laku yang membuat orang lebih istimewa. (Nasharuddin, 2015:207). Dengan kata lain dapat diartikan bahwa akhlak adalah cara manusia bertingkah laku, cara bergaul maupun cara untuk bersikap, baik bertingkah laku terhadap Allah SWT maupun bertingkah laku terhadap manusia dan makhluk hidup di sekitar kita, sesuai dengan syari'at Islam.

Dalam Kamus Bahasa Arab mengatakan akhlak berasal dari kata "خلق" yang berarti kejadian, menurut kejadiannya yaitu kejadian baik dan kejadian buruk. Sedangkan menurut istilah yang dikemukakan oleh Abuddin Nata dalam bukunya mengatakan bahwa akhlak merupakan perbuatan yang baik atau yang buruk, dalam perbuatan baik ia melakukannya dan terhadap perbuatan buruk ia menghindarinya (Abuddin Nata,2013:13).

Akhlak merupakan dorongan kejiwaan seseorang untuk melakukan sesuatu. Jika 
sesuatu yang dilakukan baik menurut syari'at dan akal, maka akhlak seseorang itu disebut berprilaku akhlak baik. Jika seseorang melakukan yang buruk menurut syari'at dan akal, maka seseorang itu disebut berprilaku buruk. (Nasharuddin,2015:208).

Berdasarkan dari bermacam pengertian akhlak, dapat penulis simpulkan bahwa tidak ada batasan dalam berprilaku, hanya saja tergantung kepada manusianya yang mau menerapkan berprilaku baik atau buruk. Sebab apasaja perbuatan, amalan dan aktivitas yang mencakup semua kegiatan, usaha dan upaya manusia yaitu adanya nilai-nilai perbuatan.

Menurut (Nasharuddin,2015,213) akhlak dalam perspektif Islam diartikan secara komprehensif (kaffah) dan holistik, dimana dan kapan saja mesti berakhlak. Oleh karena itu, akhlak merupakan sifat-sifat dan tingkah laku manusia dan akhlak tidak pernah berpisah dengan aktivitas manusia.

Setelah kita mengerti tenteng pengertian akhlak, berikut ini penulis akan menjelaskan pentingnya akhlak dalam kehidupan manusia khususnya remaja, antara lain akhlak untuk membentuk kepribadian remaja dan akhlak untuk membina kepribadian remaja.]Implementasi akhlak pergaulan Islami perlu untuk diketahui dan dilaksanakan oleh remaja. Akhlak yang dimaksud yaitu akhlak pergaulan Islami yang sesuai dengan Alquran dan sunnah. Jadi, akhlak pergaulan Islami merupakan tingkah laku seseorang yang sesuai dengan ajaran Islam. Apabila ia bertingkah laku baik maka akan berakhlak baik pula dalam pelaksanaannya, begitu juga sebaliknya apabila ia bertingkah laku buruk maka akan berakhlak buruk (tercela) pulalah dalam pelaksanaannya.

Menurut Yatimin Abdullah, mengatakan bahwa ada dua macam akhlak dalam perspektif Islam, yaitu akhlaqul karimah (akhlak terpuji) dan akhlaqul madzmumah (akhlak tercela). (Yatimin,2015). Sedangkan Rosihon Anwar membagi akhlak berdasarkan sifatnya menjadi dua bagian yaitu, akhlak mahmudah (akhlak terpuji) tang termaksud dalam sifat ini meliputi taat ibadah, menepati janji, sabar, syukur, jujur, qona'ah, Amanah, sopan sopan santun dan tawadhu'. dan akhlak madzmumah (akhlak tercela) yang termaksuk ke dalam sifat ini yaitu syirik, riya;, kufur, takabbur, iri, dengki, demdam, dan putus asa. (Rosihon,2013).

Dari paparan di atas dapat penulis simpulkan mengenai macam-macam akhlak yaitu akhlak Mahmudah (akhlak terpuji), adalah akhlak yang baik dan sesuai dengan ajaran Islam. Sifatnya antara lain, selalu berkata sopan santun, jujur, amanah, selalu beribadah, menutup aurat, berbakti pada kedua orang tua, menepati janji dan qona'ah. Akhlak Madzmumah (akhlak tercela), akhlak buruk yang tidak sesuai dengan ajaran Islam. Sifatnya antara lain, putus asa, iri, dengki, berkata kasar, jarang beribadah, berbohong, dan kufur.

Akhlak kepada Allah maksudnya sifat yang terdapat dalam diri seseorang yang diwujudkan dalam kehidupan yang diatur oleh Allah. Namun, apabila dilihat secara lebih spesifik ada beberapa sifat atau prilaku yang harus dimiliki oleh seseorang kepada Allah antara lain syukur, yaitu mengungkapkan rasa terimakasih kepada Allah. Tasbih, yaitu mensucikan Allah dari segi sifat, nama, dan segala kekuasaanNya. Istigfar, yaitu meminta ampun kepada Allah. Takbir, yaitu mengagungkan Allah atas segala kuasa-Nya. Do'a, yaitu memohon kepada Allah dan meminta pertolongan kepada Allah (Abdurahman,dkk,2014). 
Anisa Maulidani, Fuady Anwar, dan Wirdati: Implementasi Akhlak dalam Pergaulan Islami ...

Akhlak terhadap diri sendiri adalah sikap yang muncul dari jiwa yang berhubungan dengan pemeeliharaan dan kebaikan diri secara pribadi. Akhlak terhadap diri sendiri antara lain, sabar, syukur, tawadhu', benar dan Amanah.

Akhlak kepada keluarga adalah sikap yang muncul dari jiwa yang berhubungan dengan pemeliharaan keharmonisan dan kebaikan diri secara pribadi. Akhlak terhadap keluarga antara lain, berbakti kepada ibu bapak, adil terhadap saudara dan mendidik anak.

Akhlak kepada masyarakat adalah pengendalian diri dan tatanan cara bergaul dalam lingkungan masyarakat. Akhlak kepada masyarakat antara lain, akhlak terhadap orang yang lebih tua, akhlak terhadap teman sebaya, akhlak terhadap orang yang lebih muda dan akhlak terhadap orang yang berbeda agama. (Abdurahman,dkk,2014).

Faktor-faktor pendorong dan penghambat implementasi akhlak Pergaulan Islami menurut aliran Nativisme faktor yang berpengaruh terhadap pembentukan diri seseorang adalah faktor bawaan dari dalam diri seseorang, yang bentuknya berupa kecendrungan, bakat, akal dan lainnya. Jika seseorang sudah memiliki bawaan atau kecenderungan pada yang baik, maka dengan sendirinya orang tersebut akan menjadi baik.

Menurut aliran Empirisme faktor yang berpengaruh terhadap pembentukan diri seseorang adalah faktor dari luar, yaitu faktor lingkungan sosial, termaksuk pembinaan dan pendidikan yang diberikan. Jika pendidikan dan pembinaan yang diberikan baik kepada remaja maka akan baik pulalah akhlaknya. Begitu pula sebaliknya. Aliran ini tampak begitu percaya kepada peranan yang dilakukan oleh dunia pendidikan dan pengajaran.

Menurut aliran konvergensi pembinaan akhlak dipengaruhi oleh faktor internal, yaitu pembawaan faktor si anak dan faktor dari luar yaitu pendidikan dan pembinaan yang di buat secara khusus atau melalui interaksi dalam lingkungan sosial. Fitrah dan kecenderungan kearah yang baik yang ada di dalam diri manusia dibina secara intensif melalui berbagai metode. (Abuddin Nata,2013:143). Berdasarkan paparan tersebut bisa ditarik kesimpulan bahwa setiap diri manusia memiliki potensi dalam berakhlak, apakah potensi itu baik atau buruk, dalam penerapannya dipengaruhi oleh banyak faktor.

Kemudian berbagai faktor pendorong dan penghambat akhlak pergaulan Islami di antaranya adat kebiasaan. Adat kebiasaan adalah bentuk perilaku yang timbul dari tatanan sosial dan sudah menjadi kebiasaan sosial yang dapat mempengaruhi akhlak seseorang. Kebiasaan sosial yang timbul dari pengaruh orang-orang terdahulu di masyarakat tersebut, atau pengaruh agama, geografis suatu daerah (Hamka:1974). Selanjutnya yaitu lingkungan sosial dan rohani sangat besar pengaruhnya bagi remaja dalam proses pembentukan akhlaknya. Lingkungan pergaulan ini dapat dibagi kepada beberapa kategori antara lain lingkungan keluarga. Akhlak orang tua di rumah akan sangat mempengaruhi akhlak anaknya. Akhlak remaja ajuga kan terbentuk dan terbina di sekolah, sosok guru dan teman di sekolah yang akan mempengaruhi akhlak remaja. Lingkungan pergaulan yang bersifat umum dan bebas. Misalnya jika remaja bergaul dengan orang yang rajin ibadah maka lama kelamaan juga rajin beribadah. Hal ini sangat mempengaruhi akhlaknya (Selamat dan Samusi:2012).

Faktor selanjutnya adalah media informasi juga sangat mempengaruhi pembinaan 
akhlak remaja di Korong Balah Aie. Seperti game online, media sosial, televisi, handphone, dan situs- situs lainnya yang digunakan untuk mencari informasi.

Remaja berasal dari kata lain adolensence yang berarti tumbuh atau tumbuh menjadi dewasa. Istilah adolensence mempunyai arti yang lebih luas lagi yang mencakup kematangan mental, emosional sosial dan fisik. Hal senada di ungkapkan Santrock bahwa remaja (adolensence) diartikan sebagai masa perkembangan transisi antara anak dan masa dewasa yang mencakup perubahan biologis, kognitif, dan sosialemosional.

Para ahli umumnya sepakat bahwa rentangan masa remaja berlangsung dari usia 11-13 tahun sampai dengan 18-20 tahun. Pada rentangan periode ini terdapat beberapa indikator perbedaan yang signifikan, baik secara kuantitatif maupun kualitatif. Oleh karena itu, para ahli mengklasifikasikan masa remaja ini ke dalam dua bagian yaitu : (1) remaja awal (11-13 tahun s/d 14-15 tahun); dan (2) remaja akhir (14-16 tahun s/d 18-20 tahun). Masa remaja ditandai dengan adanya berbagai perubahan, baik secara fisik maupun psikis, yang mungkin saja dapat menimbulkan problema tertentu bagi si remaja. Apabila tidak disertai dengan upaya pemahaman diri dan pengarahan diri secara tepat, bahkan dapat menjurus pada berbagai tindakan kenakalan remaja dan kriminal. Problema yang mungkin timbul pada masa remaja diantaranya: (1) problema berkaitan dengan perkembangan fisik dan motorik, berkaitan dengan perkembangan kognitif dan bahasa, (2) problema berkaitan dengan perkembangan prilaku sosial, moralitas dan keagamaan, problema berkaitan dengan perkembangan kepribadian dan emosional. Masa remaja disebut juga masa untuk menemukan identitas diri (self identity) (M.Yusuf Ahmad, dkk,2016).

Seorang anak menerima pergaulan mempunyai tahapan-tahapan tertentu. Terdapat dua tahapan usia anak hingga mencapai masa balighnya. Tahapan pertama adalah sebelum tamyiz dan tahapan sesudah tamyiz. Tamyiz yaitu masa dimana anak-anak telah dapat membedakan mana yang baik dan mana yang buruk untuk dirinya. Pencapaian usia tamyiz akan dipengaruhi dengan pelajaran, peringatan dan arahan dari kedua orang tua yang dapat dipahami oleh anak seiring dengan pertumbuhan akal si anak (Prabowo,2017). Dalam dua tahapan tersebut orang tua memiliki penan penting dalam membina akhlak remaja.

Pergaulan menurut bahasa berasal dari kata "gaul" membahas tentang kata "gaul" pada peradaban kejayaan romawi ada suku yang bernama suku gaul yang pada waktu itu bangsa gaul menjadi budak kaum romawi, konon katanya mereka diberi nama bangsa gaul dikarenakan mereka memiliki sifat dan karakteristik yang berbeda dengan bangsa atau suku lainnya. Sedangkan pergaulan menurut istilah yaitu menjunjung tinggi kebersamaan, persekawanan, dan persaudaraan yang dimana mereka lebih cenderung memiliki sifat afatisme dan hedonisme yang artinya mereka akan melakukan apapun untuk mencapai tujuannya.( M.Yusuf Ahmad, dkk,2016).

Pergaulan adalah kontak langsung antara individu dengan individu lain, atau antara pendidik dengan anak didik. Pergaulan jugam memungkinkan menimbulkan pengertian yang mendalam antara tugas pendidik, yang wajib mendidik dan tugas anak didik yang wajib belajar. Saling mengetahui karena pergaulan tersebut dapat memudahkan usaha bimbingan dan pertolongan agar dilaksanakan dengan sebaikbaiknya (Abdullah Idi dan Safarina, 2011). 
Anisa Maulidani, Fuady Anwar, dan Wirdati: Implementasi Akhlak dalam Pergaulan Islami ...

Dengan demikian pergaulan Islami yang dimaksud dalam penulisan ini adalah interaksi antara seorang muslim dengan muslim yang lain, dalam kehidupan seharihari sesuai dengan nilai- nilai islami yang menyangkut kaidah dan nilai-nilai kesopanan di dalamnya.

Indikator-indikator pergaulan Islami dalam penalitian ini antara lain menutup Aurat, Islam telah mewajibkan perempuan untuk menutup aurat demi menjaga kehormatan diri dan kebersihan hati. Selanjutnya yaitu menjauhi perbuatan zina (berkhalwat), Islam adalah agama yang menjaga kesucian. Dalam Alquran Allah berfirman dalam surat al-Isra' ayat 32 :

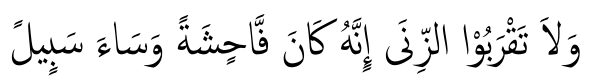

Artinya : "Dan janganlah kamu mendekati zina (zina) itu sungguh suatu perbuatan yang keji dan suatu jalan yang buruk".

Islam menjelaskan pergaulan Islami antara pria dan wanita yaitu, pria dan wanita dapat menjaga dan mengendalikan pandangan matanya dan memelihara nafsu seksualnya. Larangan berduaan sepasang muda-mudi tidak disertai mahramnya (ikhtilat). Kemudian pengaturan shaf laki-laki dan perempuan dalam shalat berjama'ah, adalah termasuk usaha pencegahan dari kemungkinan akibat jelek bagi kedua belah pihak dan rusaknya shalat itu sendiri (Muhammad, 1994).

Indikator selanjutnya yaitu mengucapkan salam saat bertemu sesama muslim dan melaksanakan solat. Dengan melaksanakan solat akan mencegah dari perbuatan keji dan munkar, dengan demikian akhlak remaja akan sendirinya berakhlakul karimah. Sebagaimana telah dijelaskan Allah Q.S Al-Ankabut : 45

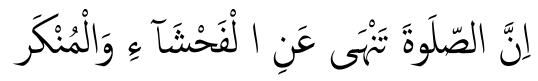

Artinya : “...Sesungguhnya sholat itu mencegah dari perbuatan keji dan munkar..."

Selanjutnya yaitu berkata sopan santun setiap bertemu orang lain dan larangan merokok atau tidak merokok bagi remaja. Berbakti kepada ibu bapak Islam mewajibkan setiap anak untuk berbakti kepada ibu bapak, karena mereka yang telah mendidik dan merawat sampai mandiri.

\section{Metode}

Pada penelitian ini menggunakan metode kualitatif dengan jenis penelitian Field research atau penelitian lapangan yaitu penelitian yang data dan informasinya didapatkan dengan cara langsung ke lapangan untuk menjelaskan serta menggambarkan mengenai situasi yang sebenarnya terjadi, pengumpulan data dilakukan dengan melakukan wawancara, observasi dan dokumentasi. Teknik analisis data yang dilakukan dengan beberapa tahapan yaitu: reduksi data, penyajian data, dan membuat kesimpulan dari data yang diperoleh. Adapun data ini diperiksa dan diuji kebenarannya dengan memakai Teknik triangulasi yaitu triangulasi sumber dan triangulasi teknik.

\section{Hasil dan Pembahasan}

Data yang disajikan ini adalah data dari hasil penelitian di lapangan dengan menggunakan Teknik pengumpulan data melalui wawancara, observasi dan dokumentasi. Hasil penelitian disajikan dalam bentuk grafik, tabel, atau deskriptif. Berdasarkan hasil wawancara yang dilakukan kepada enam orang informan, hasil analisis secara nyata mendapati bahwa terdapat delapan indikator penting terkait bagaimana sesungguhnya implementasi akhlak terhadap pergaulan Islami remaja. 
Delapan indikator tersebut dapat terlihat pada gambar 1, berikut.

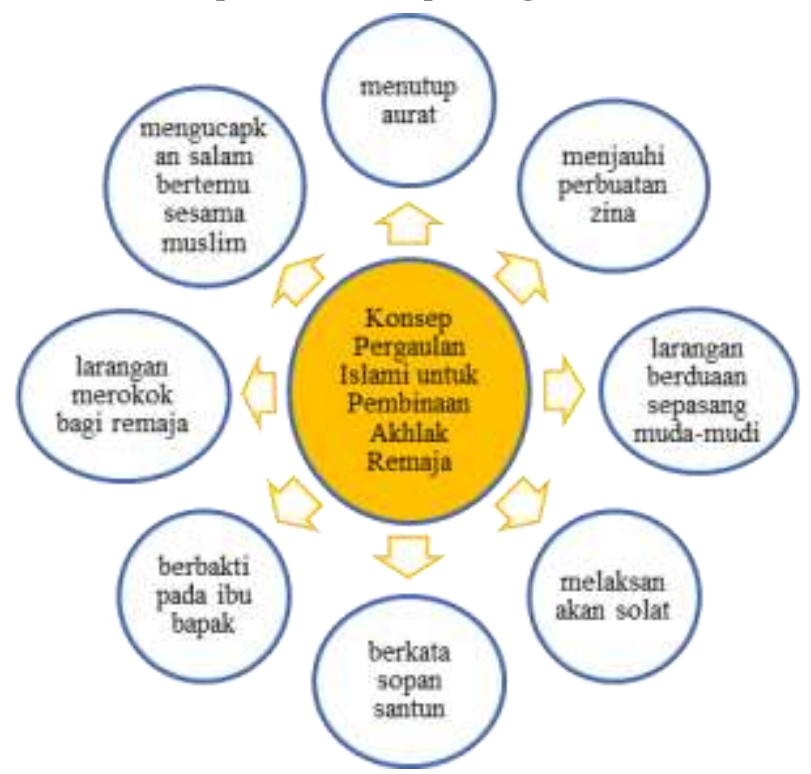

Gambar 1. Deskripsi Akhlak Pergaulan Islami Remaja

Berdasarkan gambar 1, dapat penulis jelaskan bahwa setelah diadakan wawancara mendalam dengan informan maka terdapat delapan indikator pergaulan Islami, delapan indikator tersebut adalah 1) menutup aurat, 2) menjauhi perbuatan zina, 3) larangan berduaan sepasang muda-mudi, 4) melaksanakan solat, 5) berkata sopan santun, 6) berbakti pada bapak ibu, 7) larangan merokok bagi remaja, 8) mengucapkan salam saat bertemu sesama muslim.

Agar lebih menarik, berikut ini akan penulis deskripsikan kutipan hasil wawancara dengan informan berdasarkan delapan indikator sebagaimana telah dijelaskan di atas. Adapun deskripsi wawancara yang akan penulis tampilkan adalah kutipan pernyataan singkat dari informan ketika wawancara dilakukan. Kutipankutipan wawancara tersebut walaupun disampaikan informan dalam redaksi bahasa yang sedikit berbeda-beda, namun sebenarnya mempunyai tujuan dan maksud yang kurang lebih sama.

Indikator pertama yaitu menutup aurat, Pelaksanaan dan kewajiban memakai jilbab ini penting untuk diketahui oleh orang tua maupun masyarakat agar implementasi akhlak terhadap pergaulan Islami remaja dapat diterapkan dan membentuk remaja muslim yang berakhlakul karimah. Menurut ibu Ismi (23 juni 2021), Dinda (6 juli 2021), Sahla (29 juni 2021), sebagaimana petikan wawancara pada tabel 1 berikut:

Tabel 1. Petikan Wawancara Indikator Pertama

\begin{tabular}{|l|c|l|}
\hline Indikator & Informan & \multicolumn{1}{c|}{ Petikan Wawancara } \\
\hline $\begin{array}{l}\text { Menutup } \\
\text { aurat }\end{array}$ & Ismi & $\begin{array}{l}\text { menutup aurat itu menurut saya wajib hukumnya di } \\
\text { agama islam, seseorang Wanita harus menutup auratnya } \\
\text { dengan memakai jilbab dan saya menyuruh anak saya } \\
\text { untuk memekai jilbab saat keluar rumah. }\end{array}$ \\
\cline { 2 - 3 } & Dinda & $\begin{array}{l}\text { ya, menurut saya memakai jilbab bagi perempuan itu } \\
\text { wajib bahkan dijelaskan dalam islam bahwa aurat untuk }\end{array}$ \\
\hline
\end{tabular}


Anisa Maulidani, Fuady Anwar, dan Wirdati: Implementasi Akhlak dalam Pergaulan Islami ...

\begin{tabular}{|l|l|l|}
\hline & $\begin{array}{l}\text { perempuan adalah seluruh tubuh, kecuali muka dan } \\
\text { telapak tangan, agar kita terlindungi dari orang-orang } \\
\text { yang ingin bermaksud jahat kepada kita dan saya juga } \\
\text { alhamdulillah selalu memakai jilbab saat keluar rumah }\end{array}$ \\
\cline { 2 - 3 } & Sahla & $\begin{array}{l}\text { menurut saya wajib, malu jika tidak menutupi rambut } \\
\text { dan tidak memakai jilbab. tapi kalo masih kecil memakai } \\
\text { jilbab belum wajib. jika sudah tua memakai jilbab itu } \\
\text { wajib. Dan saya kadang-kadang pakai jilbab saat keluar } \\
\text { rumah. }\end{array}$ \\
\hline
\end{tabular}

Berdasarkan wawancara diatas penulis menyimpulkan bahwa remaja dan orang tua sudah memahami kewajiban menutup aurat dalam Islam, akan tetapi masih ada beberapa remaja di Korong Balah Aie yang belum memahami tentang kewajiban menutup aurat.

Indikator kedua yaitu menjauhi perbuatan zina, menurut informan menjauhi perbuatan zina hukumnya wajib dan sesuai dengan perintah Allah dalam Q.S Al-Isra' ayat 32. Sebagaiman wawancara yang dinyatakan oleh informan pada tabel 2 berikut:

Tabel 2. Petikan Wawancara Indikator Kedua

\begin{tabular}{|l|c|l|}
\hline Indikator & Informan & \multicolumn{1}{|c|}{ Petikan Wawancara } \\
\hline $\begin{array}{l}\text { Menjauhi } \\
\text { perbuatan } \\
\text { zina }\end{array}$ & Dinda & $\begin{array}{l}\text { saya setuju, menjauhi perbuatan zina dan tidak } \\
\text { berpacaran karena apabila kita mendekatinya akan } \\
\text { mendatangkan banyak keburukan }\end{array}$ \\
\cline { 2 - 4 } & Fani & $\begin{array}{l}\text { menjauhi perbuatan zina tentunya wajib. Hal ini sesuai } \\
\text { dengan Q.S Al-Isra' ayat 32 yang menjelaskan bahwa } \\
\text { mendekati zina termaksuk dalam perbuatan keji dan } \\
\end{array}$ \\
& $\begin{array}{l}\text { Langkah setan. Oleh karena itu, wajib bagi seluruh } \\
\text { muslim baik itu remaja, dewas, orang tua untuk } \\
\text { menjauhi perbuatan tersebut. }\end{array}$ \\
\hline
\end{tabular}

Wawancara di atas dapat di simpulkan bahwa remaja di Korong balah aie mengatakan menjauhi perbuatan zina hukumnya wajib.

Indikator ketiga yaitu larangan berduaan sepasang muda-mudi, dengan kata lain larangan berpacaran. Indikator ini sebetulnya menarik karena informan memberikan pernyataan yang berbeda-beda ada yang mengatakan setuju untuk tidak pacaran dan ada juga yang mengatakan setuju untuk pacaran. Indikator ini dinyatakan oleh informan sebagaimana petikan wawancara pada tabel 3 berikut:

Tabel 3. Petikan Wawancara Indikator Ketiga

\begin{tabular}{|c|c|c|}
\hline Indikator & Informan & Petikan Wawancara \\
\hline $\begin{array}{l}\text { Larangan } \\
\text { berduaan } \\
\text { sepasang } \\
\text { muda- } \\
\text { mudi }\end{array}$ & Dinda & $\begin{array}{l}\text { saya tidak setuju dengan berpacaran, karena } \\
\text { berpacaran itu lebih banyak hal buruknya. Berpacaran } \\
\text { juga menimbulkan maksiat, membuat sakit hati dan } \\
\text { juga stress karena banyak fikiran. Dan saya tidak mau } \\
\text { berpacaran. }\end{array}$ \\
\hline
\end{tabular}




\begin{tabular}{|l|l|l|}
\hline Ica & $\begin{array}{l}\text { menurut saya berpacaran itu tidak ada masalah, selagi } \\
\text { kita masih "berpacaran sehat". Tidak ngapa-ngapain. } \\
\text { Justru dengan jalan pacaran, punya teman dekat kita } \\
\text { bisa saling mengenal satu sama lain }\end{array}$ \\
\hline Fani & $\begin{array}{l}\text { saya tidak setuju dengan pacarana karena sebagaimana } \\
\text { yang telah di jelaskan dalam dalam Q.S Al- Isra' ayat 32 } \\
\text { bahwa kita dilarang untuk mendekati zina. Oleh karena } \\
\text { itu sesuai dalil tersebut hukum pacarana adalah haram, } \\
\text { walaupun ada orang yang mengatasnamakan pacarana } \\
\text { islami, namun tetap saja hal itu dilarang. Selain itu } \\
\text { banyak sekali dampak negatif berpacaran, pacarana } \\
\text { dapat mengundang syahway manusia dan bisa } \\
\text { menjerumuskan pada perbuatan maksiat. }\end{array}$ \\
\hline Ibu ismi & $\begin{array}{l}\text { saya tidak setuju jika remaja berpacaran, sebab dapat } \\
\text { menganggu pelajarannya, tetapi setelah tamat sekolah } \\
\text { dia berpacaran tentu akan saya awasi. }\end{array}$ \\
\hline
\end{tabular}

Beberapa remaja di Korong balah aie yang mengaku tidak berpacaran dan ada juga diantara mereka yang menganggap berpacaran boleh-boleh saja, dan orang tua dari remaja tersebut akan mengawasi anaknya jika berpacaran.

Indikator keempat yaitu melaksanakan sholat, menurut informan melaksanakan solat lima waktu hukumnya wajib fardu 'ain (kewajiban bagi diri sendiri. Indikator ini dinyatakan oleh informan sebagaimana petikan wawancara pada tabel berikut:

Tabel 4. Petikan Wawancara Indikator Keempat

\begin{tabular}{|l|c|l|}
\hline \multicolumn{1}{|c|}{ Indikator } & Informan & \multicolumn{1}{c|}{ Petikan wawancara } \\
\hline $\begin{array}{l}\text { Melaksanakan } \\
\text { solat }\end{array}$ & Fani & $\begin{array}{l}\text { melaksanakan solat lima waktu hukumnya wajib fardu } \\
\text { 'ain (kewajiban bagi diri sendiri) bagi seluruh umat islam. } \\
\text { Solat juga rukun islam yang kedua yang wajib } \\
\text { dilaksanakan bagi semua umat }\end{array}$ \\
\hline
\end{tabular}

Remaja dikorong Balah Aie sudah mengetahui hukum solat lima waktu yaitu wajib dan mengaku telah melaksanakan solat lima waktu sehari semalam.

Indikator kelima yaitu berkata sopan santun, sesuai dengan hasil penelitian yang penulis lakukan remaja di Korong Balah Aie, sudah ada yang menerapkan untuk berkata sopan santun. namun, masih ada remaja yang belum berkata sopan santun baik pada sesama temannya maupun kepada orang yang lebih tua. Oleh sebab itu, orang tua wajib untuk membimbing, dan mengajarkan kepada anaknya agar berkata sopan santun, orang tua tentunya harus bisa menjadi panutan atau contoh teladan bagi anaknya.

Indikator keenam yaitu berbakti pada ibu bapak, menurut informan membantu orang tua adalah suatu kewajiban. Suatu hal yang diperintahkan oleh orang tua wajib dilakukan oleh anaknya kecuali perintah tersebut adalah hal maksiat atau hal yang buruk. sebagaimana terlihat pada petikan wawancara pada tabel 6 berikut: 
Anisa Maulidani, Fuady Anwar, dan Wirdati: Implementasi Akhlak dalam Pergaulan Islami ...

Tabel 6. Petikan Wawancara Indikator Keenam

\begin{tabular}{|l|c|l|}
\hline Indikator & Informan & \multicolumn{1}{c|}{ Petikan wawancara } \\
\hline $\begin{array}{l}\text { Berbakti } \\
\text { pada ibu } \\
\text { bapak }\end{array}$ & Fani & $\begin{array}{l}\text { menurut saya membantu orang tua adalah suatu kewajiban. } \\
\text { Suatu hal yang diperintahkan oleh orang tua wajib dilakukan } \\
\text { oleh anaknya kecuali perintah tersebut adalah hal maksiat } \\
\text { atau hal yang buruk. }\end{array}$ \\
\hline
\end{tabular}

Islam mewajibkan setiap anak untuk berbakti pada ibu bapak, Selain itu, remaja di korong Balah Aie rata-rata sudah memahami dan berbakti kepada orang tua. Cara berbakti pada orang tua salahsatunya yaitu mereka membantu pekerjaan orang tua. Tetapi berdasarkan observasi yang penulis lakukan masih ada remaja yang belum mau membantu pekerjaan orang tua mereka.

Indikator ketujuh yaitu larangan merokok bagi remaja, menurut informan mereka tidak setuju dengan remaja yang merokok walaupun ada Sebagian pendapat yang mengatakan hukum merokok mubah, makhruh. Namun juga ada pendapat yang mengatakan merokok hukumnya haram, dan saya setuju dengan pengharaman rokok. sebagaimana terlihat pada petikan wawancara pada tabel 7 berikut:

Tabel 7. Petikan Wawancara Indikator Ketujuh

\begin{tabular}{|l|c|l|}
\hline Indikator & Informan & \multicolumn{1}{|c|}{ Petikan Wawancara } \\
\hline $\begin{array}{l}\text { Larangan } \\
\text { bagi } \\
\text { remaja }\end{array}$ & Fani & $\begin{array}{l}\text { saya tidak setuju dengan remaja yang merokok. } \\
\text { Walaupun ada Sebagian pendapat yang mengatakan } \\
\text { hukum merokok mubah, makhruh. Namun juga ada } \\
\text { pendapat yang mengatakan merokok hukumnya haram, } \\
\text { dan saya setuju dengan pengharaman rokok. Banyak } \\
\text { sekali kerugian bagi yang merokok apalagi bagi yang } \\
\text { masih remaja, hal ini diantaranya pemborosan uang, } \\
\text { timbul penyakit dalam tubuh, kecanduan dan lain-lain. } \\
\text { Remaja perokok akan kesulitan dalam belajar, susah } \\
\text { dinasehati, kecanduan dan dampak buruk lainnya. }\end{array}$ \\
\hline & Dinda & $\begin{array}{l}\text { merokok itu menurut saya haram. Jika merokok itu baik, } \\
\text { mengapa anak bayi dilarang mendekat ata menghirup } \\
\text { asap orang yang merokok? Apalagi rokok memiliki zat- } \\
\text { zatyang berbahaya bagi tubuh. }\end{array}$ \\
\hline
\end{tabular}

Menurut para ulama' hukum merokok ada yang mengatakan mubah, makhruh dan haram. Namun terlepas dari itu merokok lebih banyak mendatangkan dampak negatifnya baik dari sisi kesehatan maupun akhlak, diantara remaja di Korong Balah Aie mengatakan tidak setuju dengan merokok.

Indikator kedelapan yaitu mengucapkan salam bertemu sesama muslim, hukumnya sunnah Jika ia mengucapkan salam, berarti ia telah mendoakan seseorang. Sedangkan menjawab salam wajib. 
Tabel 8. Petikan Wawancara Indikator Kedelapan

\begin{tabular}{|c|c|c|}
\hline Indikator & Informan & Petikan wawancara \\
\hline $\begin{array}{l}\text { Mengucapkan } \\
\text { salam } \\
\text { bertemu } \\
\text { dengan } \\
\text { sesama } \\
\text { muslim }\end{array}$ & Fani & $\begin{array}{l}\text { mengucapkan salam setiap bertemu tidak wajib } \\
\text { dilakukan melainkan sunnah. Hal ini sangat dianjurkan } \\
\text { dalam islam. Jika ia mengucapkan salam, berarti ia telah } \\
\text { mendoakan seseorang. Sedangkan menjawab salam } \\
\text { wajib. }\end{array}$ \\
\hline
\end{tabular}

Mengucapkan salam setiap bertemu tidak wajib dilakukan melainkan hukumnya sunnah. Hal ini sangat dianjurkan dalam islam. Jika seseorang mengucapkan salam, berarti ia telah mendoakan, sedangkan menjawab salam hukumnya wajib bagi setiap muslim.

\section{Simpulan}

Berdasarkan dari hasil penelitian peneliti mengenai implementasi akhlak terhadap pergaulan Islami remaja Korong Balah Aie ini dapat disimpulkan bahwa orang tua memiliki peran penting dalam menerapkan akhlak terhadap pergaulan islami remaja, tidak hanya orang tua namun masyarakat sekitar juga berperan penting, agar membentuk remaja yang memiliki akhlakul karimah. Penerapan akhlak pergaulan Islami remaja di Korong balah aie sejauh ini dikatakan kondusif dan ada banyak faktor yang mempengaruhi penerapan akhlak pergaulan islami.

\section{Referensi}

Al-Quranul Karim.

Abdurrahman, Muhammad.2019.AKHLAK:Menjadi Seorang Muslim Berakhlak Mulia.Depok:Rajawali Pres.

Abuddin Nata.2013.Akhlak Tasawuf dan Karakter Mulia. Jakarta: Raja Grafindo Persada.

Abdullah Idi dan Safarina HD.2011. Sosiologi Pendidikan Individu, Masyarakat, dan Pendidikan. Jakarta: Raja Grafindo Persada.

Andi Aniran dan Sitti Hasnah. 2013. Pendidikan Islam dan Etika Pergaulan Remaja (Studi pada Peserta Didik MAN 2 Palu). Jurnal penulisan Istiqra': Palu.

Hamka.1974. Pribadi. Jakarta: Bulan Bintang.

Kasmuri Selamat dan Ihsan Samusi.2012. Akhlak Tasawuf.Jakarta:Kalam Mulia.

Muhammad, Abu Bakar. 1994. Pembinaan Manusia Dalam Islam. Surabaya: Al Ikhlas.

Muhammad Yusuf Ahmad,dkk.2016.Etika Pergaulan Islami Santri Madrasah Aliyah (MA). Jurnal Al-Hikmah Vol 13

Nasharuddin.2015.Akhlak: Ciri Manusia Paripurna.Jakarta: PT.Raja Grafindo Persada.

Prabowo, Ari. 2017. Pentingnya Berkisah Alquran dan Sunnah bagi Anak Usia Dini Proceedings of The 2nd Annual Conference on Islamic Early Childhood Education, (Online), Vol. 2. No.2, (http://ejournal.uinsuka.ac.id/tarbiyah/conference/index.php/aciece2/paper/view/39/30, 
Anisa Maulidani, Fuady Anwar, dan Wirdati: Implementasi Akhlak dalam Pergaulan Islami ...

diakses 21 July 2021).

Yusuf Ahmad,dkk.2016.Etika Pergaulan Islami Santri Madrasah Aliyah (MA) di Pesantren Jabal Nur Kecamatan Kandis Kabupaten Siak.Jurnal AlHikmah.Vol 13. 